\title{
OPTIMUM BUSHING LENGTH IN THERMAL DRILLING OF GALVANIZED STEEL USING ARTIFICIAL NEURAL NETWORK COUPLED WITH GENETIC ALGORITHM
}

\author{
OPTIMALNA DOLŽINA PODPORE (ŠABLONE, VODILA) PRI \\ TERMIČNEM VRTANJU GALVANIZIRANEGA JEKLA Z UPORABO \\ UMETNE NEVRONSKE MREŽE IN GENETSKEGA ALGORITMA
}

\author{
Navasingh Rajesh Jesudoss Hynes ${ }^{1}$, Ramar Kumar' ${ }^{1}$, Jebaraj Angela Jennifa Sujana ${ }^{2}$ \\ ${ }^{1}$ Mepco Schlenk Engineering College, Department of Mechanical Engineering, Sivakasi, Vindhunagan, 626005 Tamil Nadu, India \\ ${ }^{2}$ Mepco Schlenk Engineering College, Department of Information Technology, Sivakasi, Vindhunagan, 626005 Tamil Nadu, India \\ findhynes@yahoo.co.in, mepcokumar@gmail.com, ang_jenefa@mepcoeng.ac.in
}

Prejem rokopisa - received: 2016-09-27; sprejem za objavo - accepted for publication: 2017-01-24

Thermal drilling is a novel sheet-metal-hole-making technique that utilizes the heat produced at the interface of the rotating conical tool and workpiece in order to soften the workpiece and pierce a hole into it. In this work, experiments with thermal drilling of galvanized steel were conducted based on the Taguchi $L_{27}$ orthogonal array. Significant process parameters such as rotational speed, tool angle and workpiece thickness were varied during the experimentation. In thermal drilling, the thermal-drill tool pushes aside a large amount of workpiece material to form a sleeve, which is often referred to as the bushing length. A predictive model for the bushing length was developed using a feed-forward artificial neural network based on experimental data. As the bushing length is closely associated with the tapping process, the influences of the input process parameters play a vital role in fastening galvanized steel with threaded fasteners in diverse engineering applications. The optimization problem was solved by implementing a genetic algorithm under constraint limits to maximize the bushing length. Further, a confirmation test was conducted with the intention to compare the optimum value and its corresponding bushing length predicted by the genetic algorithm. Good agreement was observed between the predicted and the experimental values.

Keywords: thermal drilling, artificial neural network, genetic algorithm, galvanized steel, bushing length

Termično vrtanje je nova, za vrtanje lukenj v pločevino, uporabljena tehnika, ki izkorišča toploto, proizvedeno na površini vrteče se konice orodja na obdelovancu z namenom, da ga zmehča in vanj naredi luknjo. V delu so bili izvedeni preizkusi na osnovi metode Taguchi $L_{27} \mathrm{z}$ ortogonalno matriko s termičnim vrtanjem galvaniziranega jekla. Pomembni parametri postopka, kot so: hitrost vrtenja, kot orodja in debelina obdelovanca, so se med eksperimentiranjem spreminjali. Pri toplotnem vrtanju, vrtanje orodja potisne stran več materiala obdelovanca tako, da se tvori navarek (rokav) okoli luknje, ki se pogosto omenja kot dolžina šablone. Napovedni model za dolžino šablone, je razvit z uporabo umetne nevronske mreže, ki temelji na znanstvenih podatkih. Ker je dolžina šablone precej povezana s procesom izdelave navoja, vplivi teh vhodnih procesnih parametrov igrajo ključno vlogo pri pritrditvi galvaniziranega jekla z navojem pritrdilnih elementov v različnih inženirskih aplikacijah. Problem optimizacije je bil rešen z implementacijo genetskega algoritma na podlagi omejitev za povečanje dolžine šablone. Ugotovljeno je bilo dobro ujemanje med napovedano in eksperimentalno vrednostjo.

Ključne besede: termično vrtanje, umetna nevronska mreža, genetski algoritem, galvanizirano jeklo, dolžina šablone

\section{INTRODUCTION}

Thermal drilling is an emerging hole-making process with significant breakthroughs in many drilling situations in both automobile and aerospace applications. This process uses the heat energy produced at the interface in order to soften and then pierce the workpiece. ${ }^{1}$ Moreover, this heat energy enhances the flow ability of the workpiece material, which is extruded onto both the front and back sides of a drilled hole. Finally, the extruded or deformed material forms a bushing shape, which surrounds the drilled hole. ${ }^{2}$ The length of the bushing formed on the workpiece after a thermal-drilling operation is called the bushing length. Achieving a sufficient bushing length is very important since the bushing length can increase the threading depth and the clamp-load-bearing capability in various engineering applications.
Contrary to the conventional drilling process, in thermal drilling, there is no chip and wastage of the material, since all the deformed material contributes to developing a bushing. As it abolishes chip generation, it can be seen as a clean, eco-friendly and chipless holemaking technique. When joining metal sheets or thinwalled structures by drilling holes using the conventional-drilling process, just one or two threads can be made in them; however, reliability is a matter of great concern in such a situation. Alternatively, weld nuts and threaded rivet nuts are used, but due to thermal distortion, they get jammed and twisted during the fastening of the structures. ${ }^{3}$ On the other hand, during the thermal-drilling process, the bushing formed is about 3 to 4 times thicker than the workpiece. The bushing thus allows a greater contact area and high structural rigidity of fasteners in joining situations. ${ }^{4}$ 
A. H. Streppel and H. J. J Kals ${ }^{5}$ suggested that the thermal-drilling process could be applied to different materials like carbon steels, stainless steel, copper, brass and aluminium. They carried out experimentation on the thermal drilling of aluminium. Due to strong pre-strain hardening, the process resulted in bad quality of the bushing. M. Kerkhofs and M. Van Stappen ${ }^{6}$ compared the performance of ( $\mathrm{Ti}, \mathrm{Al}) \mathrm{N}$ coated tungsten carbide thermal drills with uncoated drills. They reported that the coated thermal drills allowed a longer tool life than the uncoated flow drills. S. F. Miller et al. ${ }^{7}$ conducted experiments with the thermal-drilling process on steel, aluminum and titanium. They studied the properties such as the hardness and microstructure of drilled holes. They concluded that in thermal drilling large deformation and high frictional heat are generated, resulting in the changes in the material properties and microstructure of a workpiece. They reported that the thermal conductivity of the material drilled affects the quality and integrity of the hole.

S. F. Miller et al. ${ }^{8}$ conducted an experimental and numerical analysis of a thermal-drilling process on the AISI 1020 cold-rolled carbon steel under a constant feed rate. Moreover, they developed two classic models for the thermal-drilling process. They predicted the temperature distribution using a finite-element-based thermal model and in another attempt, they predicted the thrust force and torque using the basic principles of physics. S. F. Miller et al. ${ }^{9}$ thermally drilled into aluminium and magnesium alloys using tungsten carbide and titanium carbide in a cobalt matrix under different rotational speeds and feed rates. They analyzed the thrust force, torque, energy, power and peak power required for drilling. They also evaluated the formation of the bushing shape of cast metals. The bushings produced during the thermal drilling of brittle cast metals demonstrated a radial fracture. In their conclusions, they suggested to pre-heat a cast metal workpiece and create a high rotational speed for obtaining a cylindrically shaped bushing without a significant radial fracture.

S. F. Miller et al. ${ }^{10}$ developed a three-dimensional finite-element model for the thermal-drilling process in order to evaluate the plastic strain and deformation of a workpiece. S. F. Miller et al. ${ }^{11}$ investigated thermal-drill tool-wear characteristics during the thermal drilling of an AISI 1015 carbon steel workpiece. Furthermore, the thrust force and torque were analyzed. They concluded that the carbide tool is durable and it demonstrates the least tool wear after drilling 11.000 holes. However, progressively severe abrasive grooving on the tool tip was observed. S. M. Lee et al. ${ }^{12}$ carried out thermal drilling into the IN-713LC super alloy under different rotation speeds and feed rates. They investigated the material properties such as hardness, roundness, and surface roughness of the holes drilled into the IN-713LC super alloy. They reported that the hardness is higher near the wall of a drilled hole and it decreases with the increasing distance from the edge of the hole. In addition to that, higher rotational speeds and feed rates demonstrate better roundness and lower surface roughness.

H. M. Chow et al. ${ }^{13}$ optimized the process parameters of a thermally drilled austenite stainless-steel workpiece using the Taguchi method. ${ }^{14}$ They considered the input parameters such as friction angle, friction/contact-area ratio, feed rate and drilling speed, and studied their influence on the response parameters like surface roughness. Moreover, the hardness and microstructural aspects of drilled holes were studied. It was observed that the surrounding area of a drilled hole acquired a fine grain size and a compact structure with a higher microhardness than that of the area away from the drilled region. S. M. Lee et al. ${ }^{15}$ employed thermal drilling for the AISI 304 stainless steel using tungsten carbide drills with and without coating. Their results illustrated that at the same rotational speed and for the same number of holes drilled, the coated drills experienced less tool wear than the uncoated drills. Furthermore, they investigated the changes in the relationship between the drilled-surface temperature, tool wear and axial thrust force.

W. L. Ku et al. ${ }^{16}$ optimized the parameters of thermal drilling into austenite stainless steel using the Taguchi method. They studied the effects of the friction angle, friction/contact-area ratio, feed rate and rotational speed on the response-quality characteristics such as the surface roughness and bushing length. They revealed that at optimized drilling conditions, the bushing length of a drilled hole was nearly three times longer than the plate thickness, and a mirror-like quality wall surface of the drilled hole could be obtained. M. Folea et al. ${ }^{17}$ investigated the thermal drilling of a maraging-steel workpiece. The authors reported that the temperature was the most important factor in the thermal-drilling process. They also revealed that a greater quality of the holes drilled into maraging steel could be achieved with higher rotational speeds. T. K. Mehmet et al. ${ }^{18}$ studied the effects of the thermal-drilling parameters such as friction angle, friction/contact-area ratio, feed rate and rotational speed on workpiece temperature, thrust force and torque in thermal drilling of the ST12 material. They revealed that the thrust force and torque reduce with the increasing rotational speed and increase with the friction angle, feed rate and friction/contact-area ratio.

D. Biermann and Y. Liu ${ }^{19}$ demonstrated the feasibility of the thermal drilling of a magnesium wrought alloy and analyzed the thrust forces and torque. They measured the process temperature online and examined the strength of the joint through tapping and thread forming. B. B. Mehmet ${ }^{20}$ experimentally and numerically investigated the thermal drilling of the AISI 1020 steel. In their study, an analytical model for the torque, axial power and heat-transfer coefficient was developed. Good agreement was observed between experimental and numerical values. 
Similar work was performed by P. Krasauskas et al. ${ }^{21}$ on the thermal drilling into the AISI 304 steel. P. D. Pantawane and B. B. Ahuja ${ }^{22}$ carried out regression modelling of the thermal drilling of the AISI 1015 steel using the Taguchi method. They studied the effects of the tool-diameter ratio and rotational speed on the material thickness and the effect of the feed on the response parameters including the thrust force, torque and surface roughness of drilled holes. G. Somasundaram et al. ${ }^{23}$ carried thermal drilling on the Al-SiC composite material and studied the roundness errors on drilled holes. They considered the input process parameters such as the composition of workpiece, workpiece thickness, rotational speed and feed rate. They developed an empirical relation between the process parameters and the roundness error using the response surface methodo$\log$.

Artificial neural network (ANN) is a biologically inspired computer program designed to simulate the way, in which the human brain processes information. ${ }^{24}$ ANN is widely applied in modeling many machining operations like turning, milling and drilling. S. R. Karnik and V. N. Gaitone ${ }^{25}$ used a multilayer feed-forward ANN to predict the influence of the process parameters such as the cutting speed, feed, drill diameter, point angle and lip-clearance angle on the burr height and burr thickness in drilling the AISI 316L stainless steel. R. S. Mamilla et al. ${ }^{26}$ applied a multilayer ANN for modeling an abrasive flow-finishing process on the AISI 1040 and AISI 4340 steel. S. Assarzadeh and M. Ghoreishi ${ }^{27}$ successfully used a multilayer ANN for modeling the metal-removal rate and surface roughness in an electrical discharge machining process involving the BD3 steel. O. Babur et al. ${ }^{28}$ developed an ANN model according to experimental measurement data for the end milling of Inconel 718 . They coupled a genetic algorithm (GA) with an ANN to forecast the surface roughness. S. Sarkar et al. ${ }^{29}$ produced a multilayer feed-forward-ANN model to predict the process parameters of the machining of $\gamma$ titanium aluminide with a wire-electrical-discharge machine. A. K. Singh et al. ${ }^{30}$ used a multilayer feed-forward ANN to predict the flank wear of high-speed steel drill bits for drilling holes into a copper workpiece.

The literature review on thermal drilling reveals that experimental investigations and numerical simulations of the effects of mechanical and physical properties on the thermal-drilling process was mainly carried out on copper, brass, aluminium, magnesium and stainless-steel alloys, maraging steel, ST12 steel and IN-713LC super alloy. Galvanized steel is being widely used for car body structures and it is a good candidate for the implementation of the thermal-drilling process. The application of galvanized steel is widely used in the areas of roofing material, doors, ship's ducts and panels, electricalappliance automobile parts, etc. ${ }^{31}$

In the present work, thermal drilling was carried out on galvanized steel. Based on experimental measurement data, an ANN model was developed to predict the formation of the bushing length in thermal drilling of galvanized steel. This model considers rotational speed, tool angle and workpiece thickness as significant thermal-drilling process parameters. Then the optimum values of these drilling parameters were computed, with the aim of achieving the maximum bushing length, by solving the optimization problem implementing a GA. Thus, the present work allows us to achieve the maximum bushing length, which is highly desirable for the subsequent tapping and joining in automotive applications. A schematic diagram of the combined ANN-GA optimization $^{24}$ is shown in Figure 1. It indicates the stages of the GA process and its relation with the ANN process.

\section{THERMAL DRILLING}

\subsection{Physical description of the process}

Figure 2 shows a schematic representation of the thermal-drilling process. Based on the thermal-drill geometry, there are four steps involved in thermal drilling. Initially, the center point zone of a drill approaches and pierces the workpiece. Secondly, the produced heat softens the workpiece as a result of the friction between the thermal drill and the workpiece. Thirdly, the softened material is pushed downward and the drill moves forward to form the bushing using the cylindrical zone of the tool. Fourthly, the extruded burr on the workpiece surface is pressed to form a boss with the shoulder zone

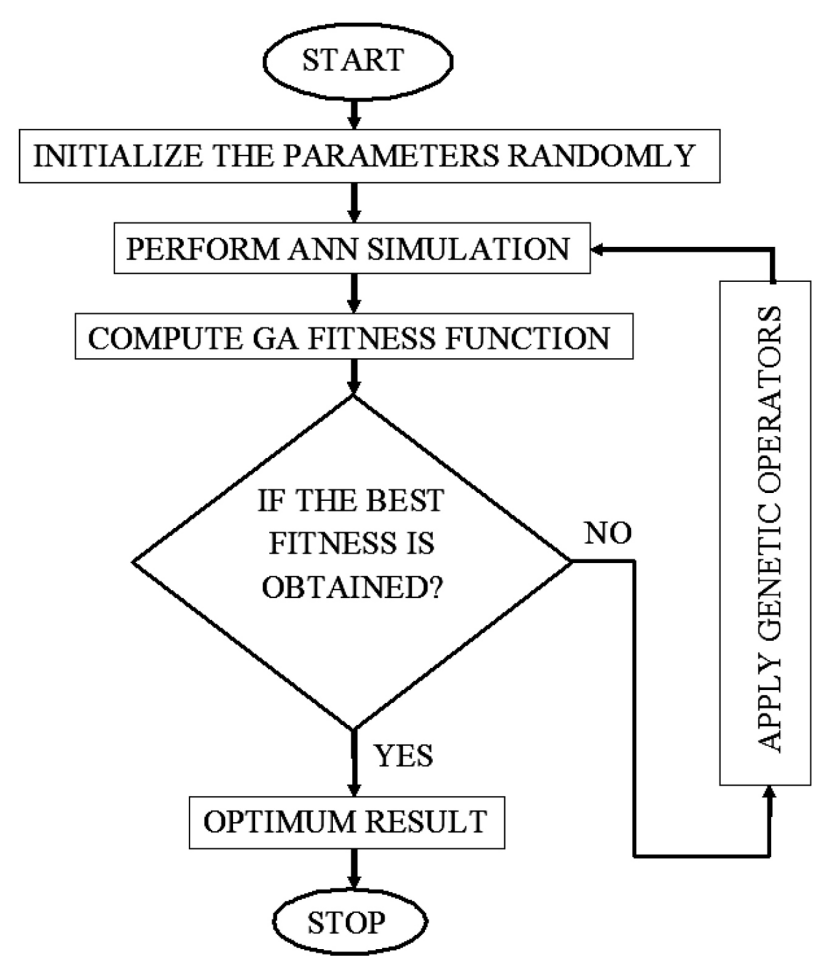

Figure 1: Flow chart of the integrated ANN-GA optimization process 
N. R. J. HYNES et al.: OPTIMUM BUSHING LENGTH IN THERMAL DRILLING OF GALVANIZED STEEL ...

of the thermal drill. Finally, the thermal drill retracts leaving a hole with a bushing length. ${ }^{37}$

\subsection{Formation of the bushing length}

The initial volume of the material $\left(V_{\mathrm{i}}\right)$ available to produce a hole by thermal drilling is given in Equation (1). ${ }^{33}$ As shown in Figure 2, $D_{1}$ and $P_{\mathrm{t}}$ represent the inner-hole diameter in $\mathrm{mm}$ and the thickness of the workpiece in $\mathrm{mm}$, respectively.

$$
V_{i}=\frac{\pi}{4} D_{1}^{2} P_{\mathrm{t}}
$$

During thermal drilling, the volume of the material to be displaced $\left(V_{\mathrm{f}}\right)$ in order to produce a bushing is given in Equation (2). ${ }^{33}$ As shown in Figure 2, $D_{2}$ and $L$ represent the outer-bushing diameter in $\mathrm{mm}$ and the bushing length in $\mathrm{mm}$, respectively.

$$
V_{f}=\frac{\pi}{4}\left[D_{2}^{2}-D_{1}^{2}\right] L
$$

It is known that the initial approximation of the volume of the material for producing a hole is the same as the volume of the material to be displaced during the formation of the bushing. Therefore, Equations (1) and (2) are assumed to be equal. Equating Equations (1) and (2), Equation (3) is obtained:

$$
\frac{\pi}{4} D_{1}^{2} P_{\mathrm{t}}=\frac{\pi}{4}\left[D_{2}^{2}-D_{1}^{2}\right] L
$$

While rearranging the terms in Equation (3), the bushing length (L) can be determined as shown in Equation (4):

$$
L=\frac{D_{1}^{2}}{\left[D_{2}^{2}-D_{1}^{2}\right]} P_{\mathrm{t}}
$$

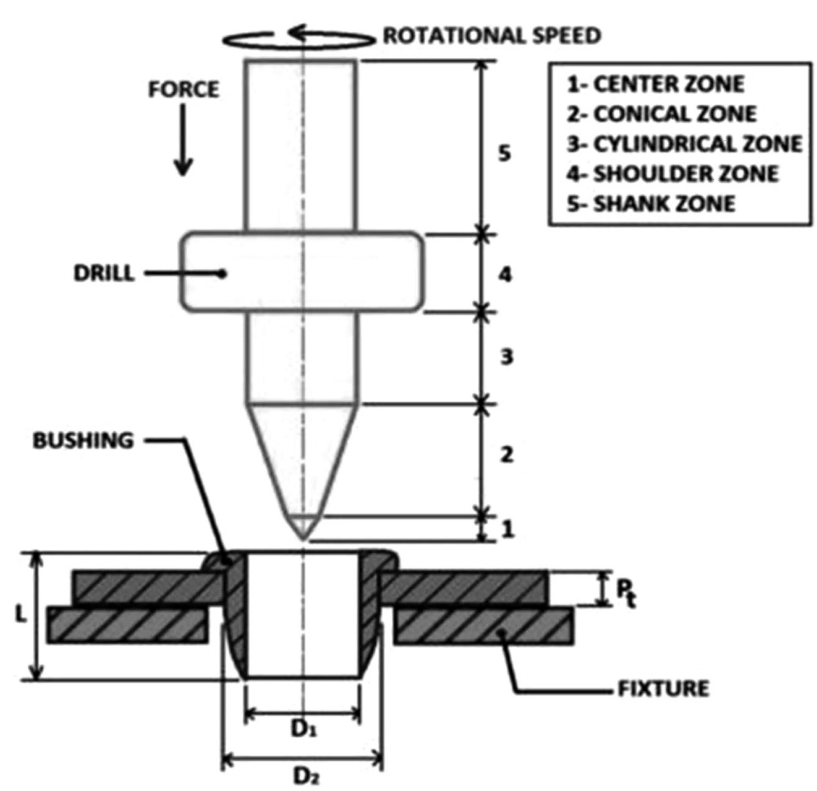

Figure 2: Schematic representation of the thermal-drilling process

\section{EXPERIMENTAL PART}

In the present work, the experiments were carried out at in a vertical drilling machine. A hot-dip-galvanized steel workpiece with thickness values of $1,1.5,2 \mathrm{~mm}$ and with dimensions of $50 \mathrm{~mm} \times 150 \mathrm{~mm}$ was used. 6-mm-diameter thermal drills with different tool angles were used in the experimentation. They were machined out of high-speed steel rods, having the required dimensions as shown in Figure 3. The feed rate of the thermal-drilling process is kept constant at $240 \mathrm{~mm} / \mathrm{min}$. The chemical composition of the galvanized steel is given in Table 1. Axial forces were measured using a digital drilling-tool dynamometer. Temperature measurements were done on-line using a non-contact-type infra-red thermometer and the temperature profile of the process was obtained using the DATA TEMP MX software with a time increment of $0.016 \mathrm{~s}$. The microstructure of the holes drilled into galvanized steel was measured using a scanning electron microscope (Carl Zeiss EVO18, Germany). Three different levels of the input process parameters were used, as shown in Table 2.

Based on the proper selection of the input process parameters, the desirable output parameters can be obtained during the experimentation. The selected input process parameters such as the rotational speed, tool

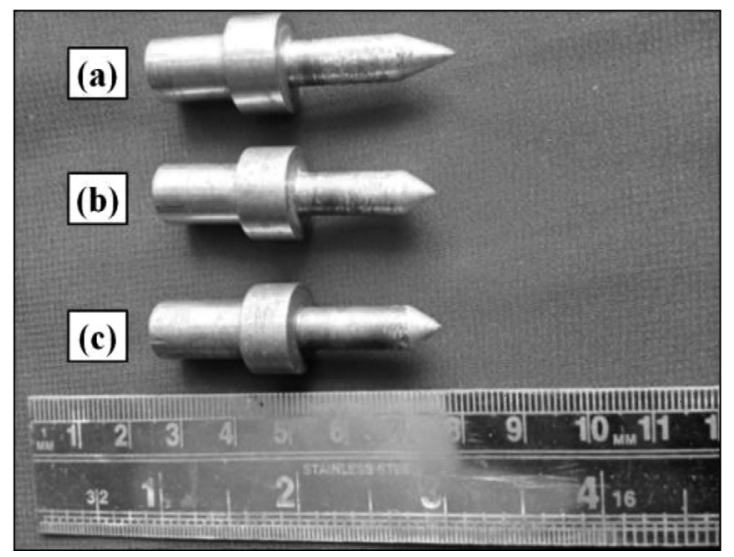

Figure 3: Obtained thermal drills with different tool angles: a) 35 degree tool angle b) 37.5 degree tool angle, c) 45 degree tool angle

Table 1: Chemical composition of galvanized steel (w/\%)

\begin{tabular}{|c|c|c|c|c|c|c|c|}
\hline $\mathrm{C}$ & $\mathrm{Si}$ & $\mathrm{S}$ & $\mathrm{P}$ & $\mathrm{Mn}$ & $\mathrm{Ni}$ & \multicolumn{2}{|c|}{$\mathrm{Cr}$} \\
\hline 0.003 & 0.006 & 0.005 & 0.018 & 0.173 & 0.011 & \multicolumn{2}{|c|}{0.031} \\
\hline $\mathrm{Mo}$ & $\mathrm{V}$ & $\mathrm{Cu}$ & $\mathrm{Al}$ & $\mathrm{Nb}$ & $\mathrm{Zn}$ & $\mathrm{Ti}$ & $\mathrm{Fe}$ \\
\hline 0.001 & 0.002 & 0.017 & 0.035 & 0.001 & 0.004 & 0.05 & Balance \\
\hline
\end{tabular}

Table 2: Input process parameters and their levels

\begin{tabular}{|l|c|c|c|}
\hline \multicolumn{1}{|c|}{ Factors } & \multicolumn{3}{c|}{ Levels } \\
\hline & 1 & 2 & 3 \\
\hline Rotational speed $\left(\mathrm{min}^{-1}\right)$ & 1944 & 2772 & 3600 \\
\hline Tool angle $\left(^{\circ}\right)$ & 30 & 37.5 & 45 \\
\hline Workpiece thickness $(\mathrm{mm})$ & 1 & 1.5 & 2 \\
\hline
\end{tabular}


angle and workpiece thickness, and the output parameter, the bushing length of the thermally drilled galvanized steel sheet, were analyzed in this work. Based on the Taguchi's $L_{27}$ orthogonal array, experiments were conducted at three levels of the drilling-process parameters and the corresponding bushing length was measured using a digital vernier caliper (Model No CD-12C, Mitutoya Corporation, Japan). All the experimental values of the bushing length are displayed in Table 3. Samples of the thermally drilled holes are shown in Figure 4. During the thermal drilling, the burr is extruded onto the top surface, and it is leveled when it comes in contact with the shoulder of the thermal-drill tool as shown in Figure 5a. The formation of the bushing at the rear side of the galvanized steel plate is shown in Figure 5b. It can be used to act as a cylindrical sleeve bearing and it can be taped to fabricate an internal screw. Additionally, it widely reduces the complexity of joining components in the aerospace and automotive industries.

Table 3: Experimental results of the thermal-drilling process

\begin{tabular}{|c|c|c|c|c|}
\hline Expt No. & $\begin{array}{c}\text { Rotational } \\
\text { speed } \\
\left(\mathrm{min}^{-1}\right)\end{array}$ & $\begin{array}{c}\text { Tool angle } \\
\left({ }^{\circ}\right)\end{array}$ & $\begin{array}{c}\text { Workpiece } \\
\text { thickness } \\
(\mathrm{mm})\end{array}$ & $\begin{array}{c}\text { Bushing } \\
\text { length } \\
(\mathrm{mm})\end{array}$ \\
\hline 1 & 1944 & 30 & 1 & 2.54 \\
\hline 2 & 1944 & 30 & 1.5 & 3.42 \\
\hline 3 & 1944 & 30 & 2 & 4.38 \\
\hline 4 & 1944 & 37.5 & 1 & 3.24 \\
\hline 5 & 1944 & 37.5 & 1.5 & 3.21 \\
\hline 6 & 1944 & 37.5 & 2 & 4.41 \\
\hline 7 & 1944 & 45 & 1 & 2.97 \\
\hline 8 & 1944 & 45 & 1.5 & 4.87 \\
\hline 9 & 1944 & 45 & 2 & 5.26 \\
\hline 10 & 2772 & 30 & 1 & 2.67 \\
\hline 11 & 2772 & 30 & 1.5 & 3.84 \\
\hline 12 & 2772 & 30 & 2 & 4.02 \\
\hline 13 & 2772 & 37.5 & 1 & 2.91 \\
\hline 14 & 2772 & 37.5 & 1.5 & 3.83 \\
\hline 15 & 2772 & 37.5 & 2 & 4.42 \\
\hline 16 & 2772 & 45 & 1 & 2.94 \\
\hline 17 & 2772 & 45 & 1.5 & 4.31 \\
\hline 18 & 2772 & 45 & 2 & 5.57 \\
\hline 19 & 3600 & 30 & 1 & 3.55 \\
\hline 20 & 3600 & 30 & 1.5 & 4.64 \\
\hline 21 & 3600 & 30 & 2 & 5.84 \\
\hline 22 & 3600 & 37.5 & 1 & 2.78 \\
\hline 23 & 3600 & 37.5 & 1.5 & 3.85 \\
\hline 24 & 3600 & 37.5 & 2 & 5.92 \\
\hline 25 & 3600 & 45 & 1 & 2.42 \\
\hline 26 & 3600 & 45 & 1.5 & 4.42 \\
\hline 27 & 3600 & 45 & 2 & 5.61 \\
\hline
\end{tabular}

\section{ARTIFICIAL-NEURAL-NETWORK MODELING}

Recently, the use of the artificial intelligence performance has been remarkable in the entire engineering field. ${ }^{24}$ To understand and manage any industrial course
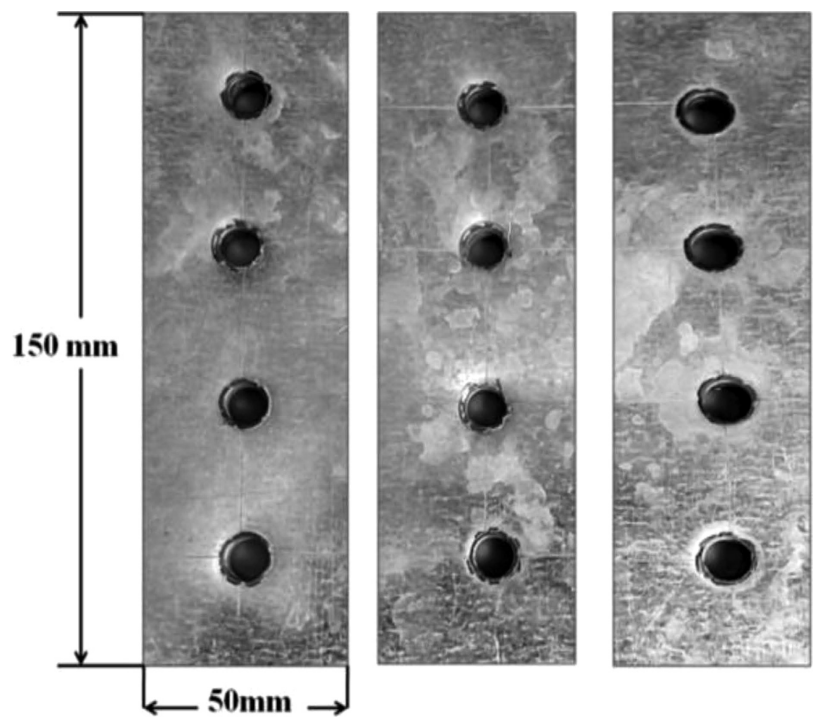

Figure 4: Holes made by thermal drilling in galvanized steel plates

of action, modeling and optimization of the process are essential. An accurate control is a requirement necessary to accomplish better quality and productivity. ANN plays a significant role in forecasting the solutions for nonlinear problems in all engineering fields. Using statistical techniques, numerous researchers endeavored to develop a model based on experimental data. In general, a neural network represents a network of many processors operating in parallel. Each processor contains a small size of the local memory. Then, these units are coupled through communication channels, which typically carry numeric data. An excellent instance of a biological neural network is the brain of a human. It comprises the most demanding and controlling arrangement, in which learning along with training controls the behavior of a human to take action to solve any problem met in day-by-day life.

ANN can be successfully employed to predict the output parameters for any given input parameters, based on the training set for a given complex problem. ${ }^{28}$ In the

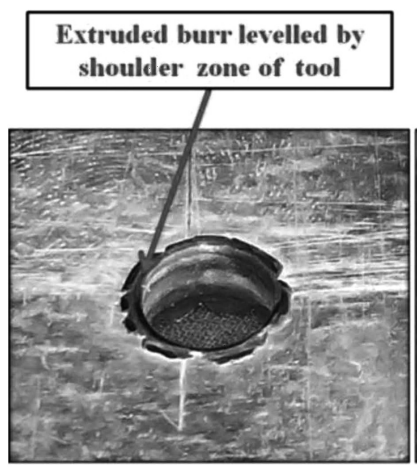

(a)

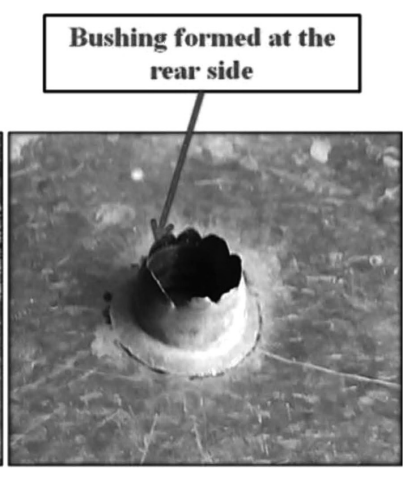

(b)
Figure 5: Appearance of a hole made by thermal drilling: a) top view and b) rear view 
N. R. J. HYNES et al.: OPTIMUM BUSHING LENGTH IN THERMAL DRILLING OF GALVANIZED STEEL ...

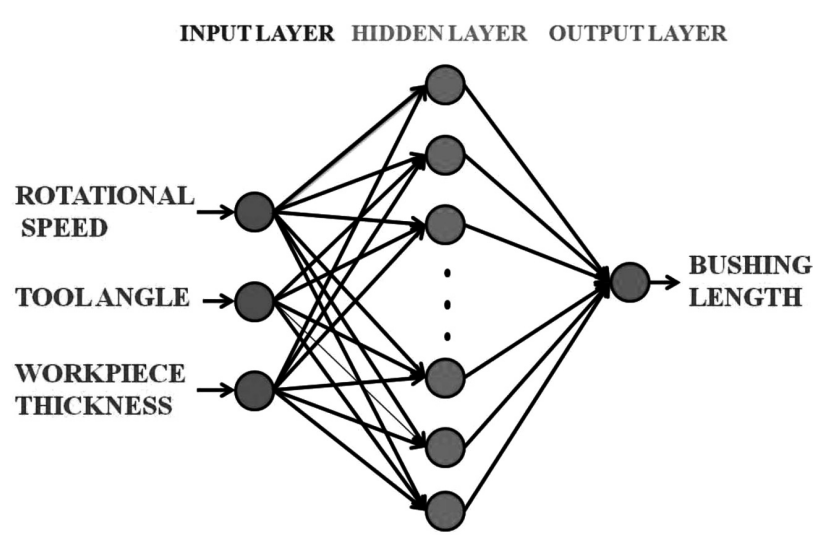

Figure 6: ANN modeling of the bushing length in thermal drilling

present work, an ANN is developed using MATLAB version 7.10, neural network toolbox, with the intention of predicting the bushing length as a function of three input process parameters including the rotational speed, tool angle and workpiece thickness. Figure 6 shows the neural-network architecture of the bushing length obtained with thermal drilling. The input data is provided through input layer neurons, and it is fed forward through the hidden layer. Then the response is obtained at the output layer neurons. The neurons are linked by weights that take part in the learning process. The weights help in attaining the optimum solution and escape from the local minima. To establish the optimum structural design, we apply the trial-and-error method with the appropriate activation function and the most excellent training algorithm. A number of models were created and tested. A hyperbolic tangent sigmoid transfer function is considered as the hidden-layer activation function, and it is given in Equation (5):

$$
f(x)=\tan \operatorname{sig}(x)=\frac{2}{1-e^{-2 x}}-1
$$

The most important selection criteria used for the suitable model are the mean squared error and the regression-coefficient value. The mean sum of the squared error (MSE) is the average squared difference between the predicted value and the actual experimental value as shown in Equation (6). A lower value of the MSE indicates a better model. The regression coefficient $(R)$ was measured by correlating the predicted and the actual values as given in Equation (7). An $R$ value of 1 indicates a close relationship between the predicted and actual experimental value, i.e., a very small error.

$$
\begin{aligned}
& M S E=\frac{1}{n} \sum_{i}\left|A_{i}-P_{i}\right|^{2} \\
& R=1-\left(\frac{\sum_{i=1}^{n}\left|A_{i}-P_{i}\right|^{2}}{\sum_{i=1}^{n}\left|P_{i}\right|^{2}}\right)
\end{aligned}
$$

where $A_{\mathrm{i}}$ is the actual experimental value, $P_{\mathrm{i}}$ is the predicted value and $n$ is the number of patterns. With the intention of measuring the accuracy of the prediction model, the percentage of error is calculated with Equation (8):

$$
z=\left|\frac{E-P}{E}\right| \times 100
$$

where $z=\%$ of prediction error, $E=$ experimental value, $P=$ predicted value

\section{RESULTS AND DISCUSSION}

The results of the ANN coupled with the $\mathrm{GA}^{34}$ are utilized to predict and optimize the bushing length based on the input process parameters such as the rotational speed, tool angle and workpiece thickness in the thermal-drilling process, and they are discussed below.

\subsection{Prediction of the bushing length by the ANN}

Table 4 displays the parameters used with this modeling technique. The developed ANN model of the bushing length was trained by means of the selected parameters. During the training process, a 19 set input for training trials were presented each time and the resultant output was acquired. The number of the hidden-layer neurons varied from 1 to 20 . It was determined based on trial and error, through step-by-step increasing the number of neurons and examining their result against the forecast value. The final neuron number of the hidden layer obtained was 10 . The ulti-
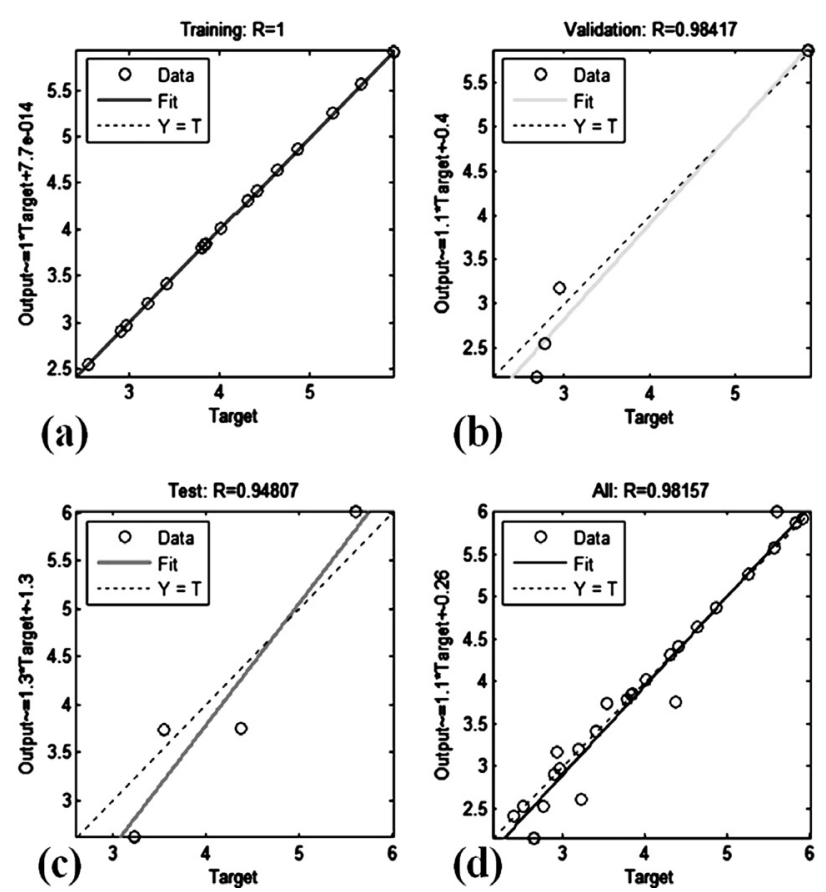

Figure 7: Correlation between the predicted values of the ANN model and the experimental data for the prediction of the bushing length using: a) training data, b) validation data, c) test data and d) entire data 
mate weights between the input layer and hidden layer (w1, w2, w3), the bias (b) and weights between the hidden layer and the output layer (w4) are shown in Table 5. Finally, the lowest MSE value achieved was 0.00415 when the configuration of the ANN was 3-10-1. There are three input neurons, each indicating one input variable form the input layer, 10 neurons in the hidden layer and the output layer with one neuron correspond to the bushing length.

Table 4: Parameters used in the ANN modeling

\begin{tabular}{|c|c|}
\hline Input variables & $\begin{array}{c}\text { Rotational speed, tool angle, } \\
\text { workpiece thickness }\end{array}$ \\
\hline Output variable & $\begin{array}{c}\text { Fushing length } \\
\text { propagation }\end{array}$ \\
\hline Network type & $\begin{array}{c}\text { Levenberg-Marquardt } \\
\text { back-propagation algorithm } \\
\text { (trainlm) }\end{array}$ \\
\hline Activation function & $\begin{array}{c}\text { Hyperbolic tangent sigmoid } \\
\text { transfer function }\end{array}$ \\
\hline Data division & $\begin{array}{c}70 \% \text { (training); } 15 \% \\
\text { (validation); } 15 \% \text { (testing) }\end{array}$ \\
\hline $\begin{array}{c}\text { Number of neurons in the } \\
\text { hidden layer }\end{array}$ & 10 \\
\hline
\end{tabular}

Table 5: Final weights in between the layers

\begin{tabular}{|c|c|c|c|c|c|}
\hline \multirow{2}{*}{$\begin{array}{c}\text { No. of } \\
\text { neurons }\end{array}$} & \multicolumn{5}{|c|}{ Weights } \\
\cline { 2 - 6 } & Input to hidden layer & $\begin{array}{c}\text { Hidden to } \\
\text { output layer }\end{array}$ \\
\cline { 2 - 6 } & $\mathrm{w} 1$ & $\mathrm{w} 2$ & $\mathrm{w} 3$ & $\mathrm{~b}$ & $\mathrm{w} 4$ \\
\hline 1 & -0.682 & -1.572 & 1.929 & 3.529 & 0.680 \\
\hline 2 & -0.865 & 1.620 & -2.115 & 2.483 & -0.576 \\
\hline 3 & 3.045 & 0.934 & -0.191 & -1.179 & 0.111 \\
\hline 4 & 1.722 & -2.097 & 1.179 & -1.184 & -0.253 \\
\hline 5 & -1.826 & -1.470 & 1.863 & 0.273 & -0.183 \\
\hline 6 & -0.027 & -0.448 & 3.025 & -0.131 & 1.113 \\
\hline 7 & -0.619 & 2.955 & 0.332 & -0.694 & 0.268 \\
\hline 8 & 0.855 & -1.318 & -2.373 & 1.895 & 0.036 \\
\hline 9 & 1.645 & 0.306 & -2.767 & 2.418 & 0.939 \\
\hline 10 & 1.822 & -1.597 & -1.613 & 3.188 & -0.638 \\
\hline
\end{tabular}

The output performance of the established ANN is examined on the basis of the regression-correlation coefficient ( $R$ value) between the predicted values and the experimental values. The predicted responses of the ANN model are in excellent conformity with the experimental values, i.e., the correlation regression coefficients of $100 \%$ for the training set, $98.41 \%$ for the validation set and $94.80 \%$ for the testing set are achieved as shown in Figure 7. It was concluded that the feed-forward back-propagation algorithm of the configuration of 3-10-1 gives the most excellent results for the prediction of the bushing length as shown in Table 6. The graphical representation of the experimental and predicted values of the bushing length by the ANN is shown in Figure 8. It shows that the ANN prediction values are very close to the experimental values of the bushing length. The average prediction error between the

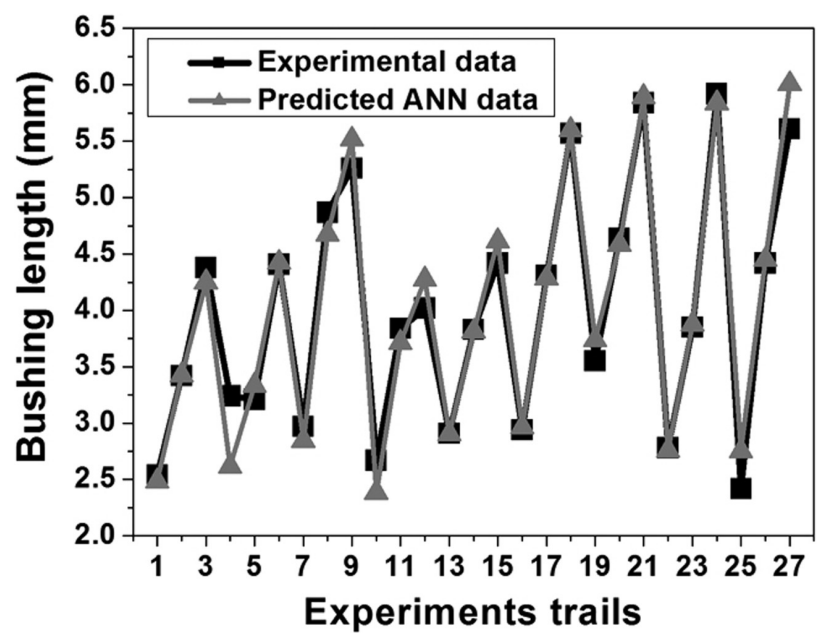

Figure 8: Correlation between experimental and predicted values

Table 6: Comparison of experimental and predicted values of the bushing length

\begin{tabular}{|c|c|c|c|}
\hline \multirow{2}{*}{ Expt No. } & \multicolumn{2}{|c|}{ Bushing length (mm) } & \multirow{2}{*}{$\begin{array}{l}\text { Prediction } \\
\text { error }(\%)\end{array}$} \\
\hline & $\begin{array}{l}\text { Experimental } \\
\text { value }\end{array}$ & $\begin{array}{c}\text { Predicted ANN } \\
\text { value }\end{array}$ & \\
\hline 1 & 2.54 & 2.485 & 2.165 \\
\hline 2 & 3.42 & 3.427 & 0.204 \\
\hline 3 & 4.38 & 4.252 & 2.922 \\
\hline 4 & 3.24 & 2.618 & 19.197 \\
\hline 5 & 3.21 & 3.336 & 3.925 \\
\hline 6 & 4.41 & 4.425 & 0.340 \\
\hline 7 & 2.97 & 2.843 & 4.276 \\
\hline 8 & 4.87 & 4.677 & 3.963 \\
\hline 9 & 5.26 & 5.517 & 4.886 \\
\hline 10 & 2.67 & 2.385 & 10.674 \\
\hline 11 & 3.84 & 3.714 & 3.281 \\
\hline 12 & 4.02 & 4.275 & 6.343 \\
\hline 13 & 2.91 & 2.905 & 0.172 \\
\hline 14 & 3.83 & 3.814 & 0.418 \\
\hline 15 & 4.42 & 4.615 & 4.412 \\
\hline 16 & 2.94 & 2.964 & 0.816 \\
\hline 17 & 4.31 & 4.284 & 0.603 \\
\hline 18 & 5.57 & 5.599 & 0.521 \\
\hline 19 & 3.55 & 3.738 & 5.296 \\
\hline 20 & 4.64 & 4.585 & 1.185 \\
\hline 21 & 5.84 & 5.893 & 0.907 \\
\hline 22 & 2.78 & 2.760 & 0.719 \\
\hline 23 & 3.85 & 3.875 & 0.649 \\
\hline 24 & 5.92 & 5.836 & 1.419 \\
\hline 25 & 2.42 & 2.755 & 13.843 \\
\hline 26 & 4.42 & 4.450 & 0.679 \\
\hline 27 & 5.61 & 6.007 & 7.077 \\
\hline
\end{tabular}

experimental and predicted values of the bushing length is $1.843 \%$. Therefore, it is demonstrated that the developed ANN model is suitable for forecasting the bushing length of drilled holes in thermal drilling of galvanized steel, having the highest accuracy of $98.157 \%$. 
N. R. J. HYNES et al.: OPTIMUM BUSHING LENGTH IN THERMAL DRILLING OF GALVANIZED STEEL ...

\subsection{Optimization of the bushing length using a GA}

The optimization of the thermal drilling process is performed using the GA in MATLAB toolbox, with the intention of enhancing the effectiveness of the drilling process in order to achieve high structural rigidity for fasteners in joining situations..$^{35,36}$ This algorithm makes a binary coding system to characterize the variables such as rotational speed (RS), tool angle (TA) and workpiece thickness (WT). All of the process variables are symbolized by a ten-bit binary equivalent. In the chromosome, the process variables are represented as a substring. The GA employs different types of crossover and mutation operators to predict the maximum values of the bushing length. At this time, the second-order mathematical model is considered as an objective function with the aim of maximizing the output bushing length (BL). In this model, the rotational speed (RS), tool angle (TA) and workpiece thickness (WT) are considered as the input parameters. The aim of the optimization is to maximize the bushing length; however, usually, a GA is used to achieve the minimum function value for a minimization problem. Hence, in the present situation, the objective function was converted into a minimization problem. A unity negative factor is multiplied to the objective function in the larger-the-best-type bushing length $(\mathrm{L})$ of the responses characteristic of thermal drilling to make them minimize the type objective. The parameters used in the GA technique are shown in Table 7. Equation (9) is a developed regression model of the bushing length and it is used as the fitness function or objective function for this problem. It is developed with the knowledge gained form ANN values. ${ }^{37,38}$

Table 7: GA parameters

\begin{tabular}{|c|c|}
\hline Population type & Double vector \\
\hline Population size & 100 \\
\hline Scaling function & Rank \\
\hline Selection function & Roulette wheel \\
\hline Elite count & 0.8 \\
\hline Crossover fraction & Adaptive feasible \\
\hline Mutation function & Heuristic \\
\hline Crossover function & 50 \\
\hline Stall generations &
\end{tabular}

Maximum bushing length $(\mathrm{L})=6.56203-4.64305 \times$ $10^{-4} \times \mathrm{RS}-0.210894 \times \mathrm{TA}-1.04080 \times \mathrm{WT}+$ $3.54118 \times 10^{-7} \times \mathrm{RS} 2-0.00413827-\mathrm{TA}^{2}-0.282222$ $\times \mathrm{WT}^{2}-5.82394 \times 10^{-5} \times \mathrm{RS} \times \mathrm{TA}+0.000668277 \times$ $\mathrm{RS} \times \mathrm{WT}+0.0584444 \times \mathrm{TA} \times \mathrm{WT}$

is subjected to constrained variables such as:

$1944 \mathrm{~min}^{-1}=\mathrm{RS}=3600 \mathrm{~min}^{-1}(\mathrm{RS}-$ rotational speed $)$

$30^{\circ}=\mathrm{TA}=45^{\circ}(\mathrm{TA}-$ tool angle $)$

$1 \mathrm{~mm}=\mathrm{WT}=2 \mathrm{~mm}$ (WT - workpiece thickness).

Figure 9 shows the bushing-length fitness-function plot obtained with the genetic algorithm. The negative sign from the final result can be eliminated to get the

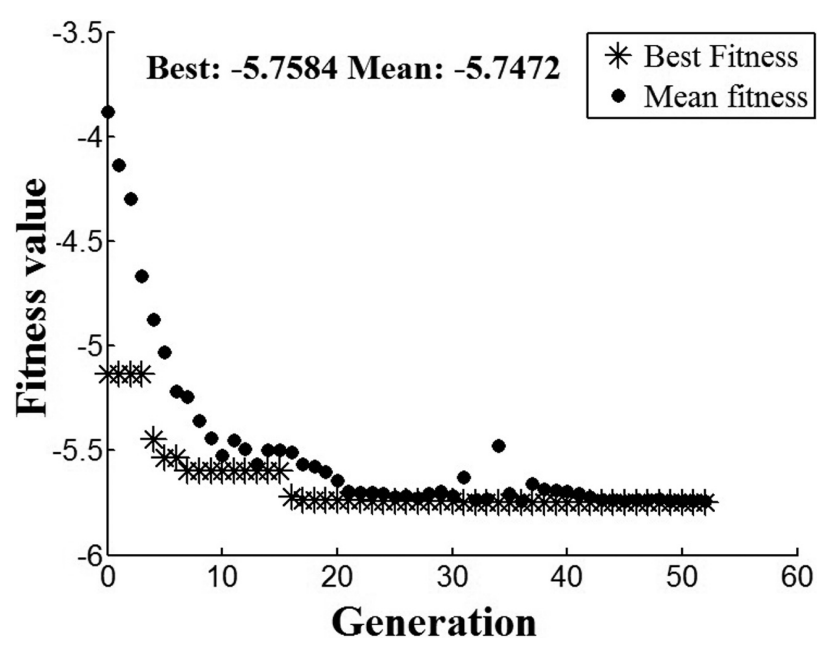

Figure 9: Fitness-function plot of the bushing length from the genetic algorithm

maximum value of the bushing length. The optimum result is achieved at the $52^{\text {nd }}$ iteration of the genetic algorithm. It is found that the mean fitness value is $5.7472 \mathrm{~mm}$, whereas the best fitness value is $5.7584 \mathrm{~mm}$. Table 8 presents the optimized and experimental value of the bushing length. Very close agreement between the optimized and experimental values of the bushing length is obtained. It confirms the potential applicability of these GA techniques for the industry-related problems. Figure 10 shows the cross-section of the bushing length of a hole drilled in galvanized steel under the condition of the optimal process parameter. The bushing length can offer a longer contact-surface area, which can uphold a shaft securely, and the drilled-hole inner surface has a thermally affected zone.

Table 8: Comparison of predicted and experimental values of the bushing length

\begin{tabular}{|l|c|c|c|c|}
\hline \multirow{2}{*}{} & \multicolumn{2}{|c|}{$\begin{array}{c}\text { Optimum drilling input } \\
\text { process parameters }\end{array}$} & $\begin{array}{c}\text { Output } \\
\text { para- } \\
\text { meters }\end{array}$ \\
\cline { 2 - 5 } & $\begin{array}{c}\text { Rota- } \\
\text { tional } \\
\text { speed } \\
\left(\mathrm{min}^{-1}\right)\end{array}$ & $\begin{array}{c}\text { Tool } \\
\text { angle } \\
\left({ }^{\circ}\right)\end{array}$ & $\begin{array}{c}\text { Work- } \\
\text { piece } \\
\text { thickness } \\
(\mathrm{mm})\end{array}$ & $\begin{array}{c}\text { Bushing } \\
\text { length } \\
(\mathrm{mm})\end{array}$ \\
\hline $\begin{array}{l}\text { Parameters optimized } \\
\text { with genetic algorithm }\end{array}$ & 3552.461 & 45 & 2 & 5.758 \\
\hline $\begin{array}{l}\text { Experimentally used } \\
\text { parameters }\end{array}$ & 3600 & 45 & 2 & 5.6 \\
\hline
\end{tabular}

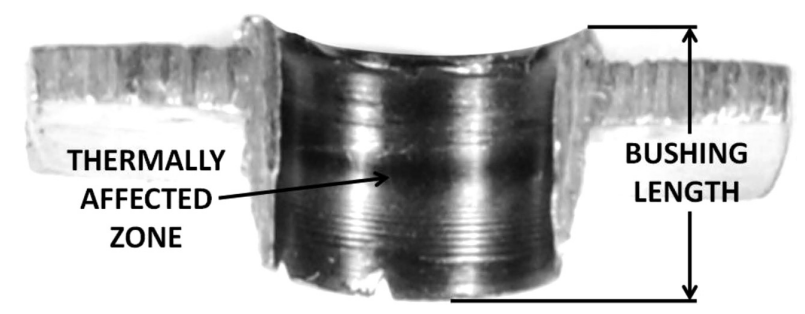

Figure 10: Cross-section of a thermally drilled hole 


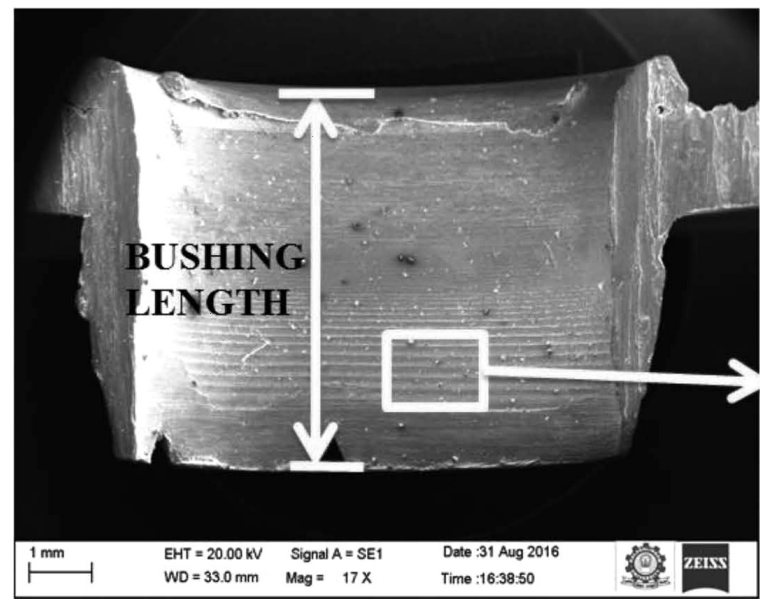

Figure 11: Microstructure of a thermally drilled hole

\subsection{Microstructural investigation}

Figure 11 shows a macrograph obtained with scanning electron microscopy at a magnification of $17 x$. The scanning electron microscope was utilized to observe and investigate the inside surface of a hole drilled in galvanized steel. During the thermal-drilling operation, the rubbing action between the interface of the thermal drill and the galvanized-steel workpiece led to a rise in the temperature of up to $798{ }^{\circ} \mathrm{C}$ as recorded on-line during the experimentation. Due to such frictional heating and application of the axial tensile force, Luders bands were formed to relieve the high amount of the internal stresses experienced in the galvanized steel. ${ }^{39,40}$ Luders bands started to form at the tail end of the bushing at a distance of $914 \mu \mathrm{m}$, after the piercing of a hole with the center zone of the thermal drill. Until a distance of $1725 \mu \mathrm{m}$, stretcher-strain markings such as Luders bands are observed in the micrograph shown in Figure 11. The width of each band thus formed is different because of non-uniform yielding of the galvanized steel during the contact with the cylindrical zone of the thermal drill.

\section{CONCLUSIONS}

The present work demonstrates the possibility of thermal drilling of galvanized steel that has tremendous applications in the domain of automobile and aerospace engineering. Owing to its importance, the mechanism and formation of the bushing length is studied.

Due to frictional heating and applied axial force, internal stresses tend to increase in that region and subsequently lead to the formation of Luders bands at the tail end of the bushing. The formation of these stretcher-strain marks is due to discontinuous non-uniform yielding of the galvanized steel.

The relationship between the input parameters such as the rotational speed, tool angle and workpiece thickness, and the output parameters like the bushing length is modeled through an ANN technique. The developed

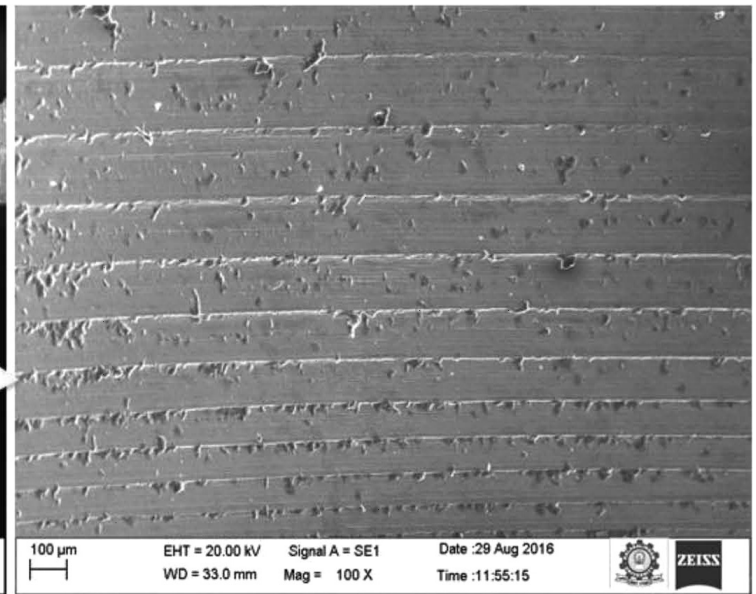

ANN model is appropriately incorporated with the GA to optimize the thermal-drilling process parameters.

A good correlation was observed between the experimental measurements and the predicted optimum values. This shows that the ANN model combined with the GA can be successfully applied to find the optimum conditions for achieving the maximum bushing length in the thermal drilling of galvanized steel.

The modeling and optimization are valid for one material and coating only. For different materials, the building of a new ANN model is required, and the genetic optimization is to be performed again.

\section{Acknowledgements}

The authors are grateful for the financial grant by the Mepco Schlenk Engineering College (Autonomous), Sivakasi, under the Students Project Scheme (Letter No. OF/EDC/2840/2015-2016 dated 24.10.2015) for establishing an experimental set-up. The authors acknowledge the support and encouragement by Dr. S. Arivazhagan, Principal and Dr. P. Nagaraj, Head of Mechanical Engineering, towards this work.

\section{REFERENCES}

${ }^{1}$ N. R. J. Hynes, M. V. Maheshwaran, Numerical analysis on thermal drilling of aluminum metal matrix composite, AIP. Conf. Proc., 1728 (2016), 1-5, doi:10.1063/1.4946597

${ }^{2}$ O. Cebeli, D. Zulkuf, Investigate the friction drilling of aluminium alloys according to the thermal conductivity, Tem. J., 2 (2013) 1 , 93-101

${ }^{3}$ S. F. Miller, Experimental analysis and numerical modeling of the friction drilling process, Thesis, University of Michigan, 2006

${ }^{4}$ N. R. J. Hynes, M. Muthukumaran, N. Rakesh, C. K. Gurubaran, Numerical analysis in friction drilling of AISI1020 steel and AA 6061 T6 alloy, Recent Advances in Environmental and Earth Sciences and Economics, 39 (2015), 145-149

${ }^{5}$ A. H. Streppel, H. J. J Kals, Flow drilling: a preliminary analysis of a new bush-making operation, CIRP Ann. Manuf. Techn., 32 (1983) 1, 167-171, doi:10.1016/S0007-8506(07)63383-6 


\section{N. R. J. HYNES et al.: OPTIMUM BUSHING LENGTH IN THERMAL DRILLING OF GALVANIZED STEEL ...}

${ }^{6}$ M. Kerkhofs, M. Van Stappen, The performance of (Ti, Al) N-coated flow drills, Surf. Coat. Technol., 68 (1994) 69, 741-746

${ }^{7}$ S. F. Miller, P. J. Blau, A. J. Shih, Microstructural alterations associated with friction drilling of steel, aluminum, and titanium, J. Mater. Eng. Perform., 14 (2005), 647-653, doi:10.1361/ $105994905 X 64558$

${ }^{8}$ S. F. Miller, R. Li, H. Wang, A. J. Shih, Experimental and numerical analysis of the friction drilling process, J. Manuf. Sci. Eng., 128 (2006), 802-810, doi:10.1115/1.2193554

${ }^{9}$ S. F. Miller, J. Tao, A. J. Shih, Friction drilling of cast metals, Int. J. Mach. Tools Manuf., 46 (2006), 1526-1535, doi:10.1016/ j.ijmachtools.2005.09.003

${ }^{10} \mathrm{~S}$. F. Miller, A. J. Shih, Thermo-mechanical finite element modeling of the friction drilling process, J. Manuf. Sci. Eng., 129 (2007), 531-538

${ }^{11}$ S. F. Miller, P. J. Blau, A. J. Shih, Tool wear in friction drilling, Int. J. Mach. Tools Manuf., 47 (2007), 1636-1645, doi:10.1016/ j.ijmachtools.2006.10.009

${ }^{12}$ S. M. Lee, H. M. Chow, B. H. Yan, Friction drilling of IN-713LC cast superalloy, Mater. Manuf. Proces., 22 (2007), 893-897, doi:10.1080/10426910701451697

${ }^{13}$ H. M. Chow, S. M. Lee, L. D. Yang, Machining characteristic study of friction drilling on AISI 304 stainless steel, J. Mater. Process. Technol., 207 (2008), 180-186, doi:10.1016/j.jmatprotec.2007. 12.064

${ }^{14}$ B. Mehmet, C. Ibrahim, G. Mustafa, O. Feridun, Application of the taguchi method to optimize the cutting conditions in hard turning of a ring bore, Mater. Tech., 49 (2015) 5, 765-772, doi:10.17222/mit. 2014.246

${ }^{15}$ S. M. Lee, H. M. Chow, F. Y. Huang, B. H. Yan, Friction drilling of austenitic stainless steel by uncoated and PVD AlCrN- and TiAlN-coated tungsten carbide tools, Int. J. Mach. Tools Manuf., 49 (2009), 81-88,doi:10.1016/j.ijmachtools.2008.07.012

${ }^{16}$ W. L. Ku, C. L. Hung, S. M. Lee, H. M. Chow, Optimization in thermal friction drilling for SUS 304 stainless steel, Int. J. Adv. Manuf. Technol., 53 (2011), 935-944, doi:10.1007/s00170-010-2899-5

${ }^{17}$ M. Folea, D. Schlegel, E. Gete, C. Langlade, A. Roman, Preliminary tests on flow drilling of maraging steels, Acad. J. Manuf. Eng. 10 (2012) 4, 42-47

${ }^{18}$ T. K. Mehmet, A. Alaattin, B. Bertan, K. A. Hamza, An experimental study on friction drilling of ST12 steel, T. Can. Soc. Mech. Eng., 38 (2014), 319-329

${ }^{19}$ D. Biermann, Y. Liu, Innovative flow drilling on magnesium wrought alloy AZ31, Proc. CIRP., 18 (2014), 209-214, doi:10.1016/j.procir. 2014.06.133

${ }^{20}$ B. B. Mehmet, G. Kadir, G. Arif, Three-dimensional finite element model of friction drilling process in hot forming processes, J. Proc. Mech. Eng., (2015), 1-7, doi:10.1177/0954408915614300

${ }^{21}$ P. Krasauskas, S. Kilikevičius, R. Česnavičius, D. Pačenga, Experimental analysis and numerical simulation of the stainless AISI 304 steel friction drilling process, Mecha., 20 (2014) 6, 590-595, doi:10.5755/j01.mech.20.6.8664

${ }^{22}$ P. D. Pantawane, B. B. Ahuja, Parametric analysis and modelling of friction drilling process on AISI 1015, Int. J. Mecha. Manuf. Sys., 7 (2014) 1, 60-79, doi:10.1504/IJMMS.2014.062771

${ }^{23}$ G. Somasundaram, B. S. Rajendra, K. Palanikumar, Modeling and analysis of roundness error in friction drilling of aluminum silicon carbide metal matrix composite, J. Compos. Mater., 46 (2011) 2, 169-181, doi:10.1177/0021998311410493

${ }^{24}$ S. Changyu, W. Lixia, C. Wei, W. Jinxing, Optimization for injection molding process conditions of the refrigeratory top cover using combination method of artificial neural network and genetic algorithms, Poly. Plast. Tech. Eng., 46 (2007), 105-112, doi:10.1080/ 03602550601152853
${ }^{25}$ S. R. Karnik, V. N. Gaitone, Development of artificial neural network models to study the effect of process parameters on burr size in drilling, Int. J. Adv. Manuf. Technol., 39 (2008), 439-453, doi:10.1007/s00170-007-1231-5

${ }^{26}$ R. S. Mamilla, S. Mondal, J. Ramkumar, V. K. Jain, Experimental investigations and modeling of drill bit-guided abrasive flow finishing (DBG-AFF) process, Int. J. Adv. Manuf. Technol., 42 (2009), 678-688, doi:10.1007/s00170-008-1642-y

${ }^{27}$ S. Assarzadeh, M. Ghoreishi, Neural-network-based modeling and optimization of the electro-discharge machining process, Int. J. Adv. Manuf. Technol., 39 (2008), 488-500, doi:10.1007/s00170-0071235-1

${ }^{28}$ O. Babur, O. Hasan, K. Hasan, Optimum surface roughness in end milling Inconel 718 by coupling neural network model and genetic algorithm, Int. J. Adv. Manuf. Technol., 27 (2005), 234-241, doi:10.1007/s00170-004-2175-7

${ }^{29}$ S. Sarkar, S. Mitra, B. Bhattacharyya, Parametric optimisation of wire electrical discharge machining of $\gamma$ titanium aluminide alloy through an artificial neural network model, Int. J. Adv. Manuf. Technol., 27 (2006), 501-508, doi:10.1007/s00170-004-2203-7

${ }^{30}$ A. K. Singh, S. S. Panda, S. K. Pal, D. Chakraborty, Predicting drill wear using an artificial neural network, Int. J. Adv. Manuf. Technol., 28 (2006), 456-462, doi:10.1007/s00170-004-2376-0

${ }^{31}$ S. M. Hamidinejad, F. Kolahan, A. H. Kokabi, The modeling and process analysis of resistance spot welding on galvanized steel sheets used in car body manufacturing, Mater. Des., 34 (2012), 759-767, doi:10.1016/j.matdes.2011.06.064

${ }^{32}$ Y. Lieh-Dai, K. Wei-Liang, C. Han-Ming, W. Der-An, L. YanCherng, Mar-M247, Haynes-230 \& Inconel-718 study of machining characteristics for Ni-based super alloys on friction drilling, Adv. Mat. Res., 459 (2012), 632-637, doi:10.4028/www.scientific.net/ AMR.459.632

${ }^{33}$ J. B. Peter, C. J. Brian, Q. Jun, Feasibility of thermally drilling automotive alloy sheet, castings, and hydro formed shapes, (2007), http://web.ornl.gov/info/reports/2007/3445605662084.pdf, 08/2016

${ }^{34}$ P. Sathiya, K. Panneerselvam, M. Y. Abdul Jaleel, Optimization of laser welding process parameters for super austenitic stainless steel using artificial neural networks and genetic algorithm, Mater. Des., 36 (2012), 490-498, doi:10.1016/j.matdes.2011.11.028

${ }^{35}$ K. Girish, S. S. Kuldip, Predictive modelling and optimization of machining parameters to minimize surface roughness using artificial neural network coupled with genetic algorithm, Proc. CIRP., 31 (2015), 453-458, doi:10.1016/j.procir.2015.03.043

${ }^{36}$ S. S. Kuldip, S. Sachin, K. Girish, Optimization of machining parameters to minimize surface roughness using integrated ANN-GA approach, Proc. CIRP., 29 (2015), 305-310, doi:10.1016/j.procir. 2015.02.002

${ }^{37}$ D. S. Nagesh, G. L. Datta, Genetic algorithm for optimization of welding variables for height to width ratio and application of ANN for prediction of bead geometry for TIG welding process, App. Soft. Comp., 10 (2010), 897-907, doi:10.1016/j.asoc.2009.10.007

${ }^{38}$ M. Z. Azlan, H. Habibollah, S. Safian, Genetic algorithm and simulated annealing to estimate optimal process parameters of the abrasive water jet machining, Eng. Comp., 27 (2011), 251-259, doi:10.1007/s00366-010-0195-5

${ }^{39}$ V. S. Ananthan, E. O. Hall, Macroscopic aspects of Luders band deformation in mild steel, Actametall. Mater., 39 (1991) 12, 3153-3160, doi:10.1016/0956-7151(91)90049-7

${ }^{40}$ F. H. Julian, K. Stelios, On the effect of Luders bands on the bending of steel tubes. Part II: Analysis, Int. J. Solids. Struct., 48 (2011), 3285-3298, doi:10.1016/j.ijsolstr.2011.07.012 